\title{
Thailand 4.0: A new value-based economy and its implication on wellness business
}

\author{
Surada Chundasutathanakul
}

\author{
School of Business \\ University of the Thai Chamber of Commerce, Thailand \\ School of Law and Politics, Suan Dusit University, Thailand \\ Suthawan Chirapanda \\ School of Business, University of the Thai Chamber of Commerce
}

\author{
Keyword \\ Healthcare and Wellness Tourism; Neo-Authoritarian Developmental State; Public Policy; \\ Value-Based Economy; Small and Medium Sized Enterprises (SMEs)
}

\begin{abstract}
The research aims to explain Thailand's value-based economy and its implications on wellness business. The research uses political and management theories namely, developmental state theory, neo-authoritarian developmental state theory, social network theory, social capital theory, diffusion of innovation theory, resource-based theory, and image theory to portray and applied into the case.

Moreover, the research is a qualitative research by nature as it uses semi-structure interviews and focus groups to find the answers. The main finding of this research is that since 2002 where the Thai government has set "Medical and Wellness Tourism" as the country's development strategy to make Thailand a "hub" for medical and wellness tourism - though the country's politics has faced two coup d'états and the country's administrations have been rough as it is controlled by different political groups - both, civilian and military, governments have followed the strategy and have highlighted medical and wellness business sector as one of their development strategies as well as policies.

The conclusion of the research is that the military government has stepped forward from solely being authoritarian state and transform the country to become a neo-authoritarian developmental state where it practices capitalism while limits people participation in politics. On top of that, the state implements policies that benefit healthcare and wellness industry, especially SMEs, to assure that it achieves the goal of being a medical and wellness hub of the region.
\end{abstract}

\section{Introduction}

In the past, Thailand had been developing the country's economy via its competitive advantage in rich natural resources and diverse biography and invested most its capital and attention in the agriculture sector, which is the 1.0 economic development phase. Then it entered the 2.0 and 3.0 phases, where the country earned the income from light industries and heavy industries, respectively. However, Thailand still faced 3 traps that blocked it from achieving expected economic growth, namely middle-income trap: inequality trap and imbalance trap. These traps combined with structural problems led to the country low competitiveness in economic development. Therefore, to frame economic development for 20 years (2017 - 2036 B.E.) forward, the government has come up with Thailand 4.0 economic development strategies that shifts the focus into innovation-based development and to connect the country's economy to the global level. (Ministry of Industry, 2016)

According to Thailand 4.0 economic development frame, the industry sector must have at least $4.5 \%$ annual growth rate and at least $10 \%$ annual investment growth rate with $8 \%$ annual export growth rate and at least $2.0 \%$ total factor productivity (TFP) growth rate per year. Those will add up Thailand to become a high-income country in 2036 as planned. Apart from that, the 20-year industry development framework will also upgrade the country's capability and global competitiveness while also creates tremendous jobs for Thais and generates income to the country, that eventually responses to the motto "Security, Wealth and Sustainability" that the government has high hope for. (Ministry of Industry, 2016) 


\section{Thailand and its political economic background}

Military and business have had strong ties since the era of military dictatorship where the military would construct a business-friendly environment for its "friends" as big business provided support for democratic transition in 1973 (Pasuk and Baker, 2004. Pp. 12 - 13). In Thai parliamentary politics, "elections were fought through vote buying, patronage, pork barrel, and professional violence", and gradually businessmen entered politics to secure their power and privilege and slowly pushing military officers out of political positions (Pasuk and Baker, 2004. Pp. 13 - 14). From friendship, relations between military and business have shifted to political rivalry at times as there were 3 coups after political transition after General Prem Tinsulanonda stepped down from his eight-year-long premiership. The transition was followed by the Black May incident of 1992 that middleclass Thais gathered to overthrow military government, demanding democracy. After the incident, the country had restored parliamentary where Bangkok's banking and provincial business secured its strong representation within highly fragment political party system and weak coalition government (Owen, 2014. pp. 122).

In 2001, Thaksin, a telecommunication business mogul turned politician, was elected and was the first prime minister to survive a full four-year term of premiership and was reelected again in 2005. Due to policy corruption and conflict of interests in Thaksin's government, in 2006, middleclass Thais, once again, gathered under People's Alliance for Democracy (PAD) to overthrow his elected government. On September 19th 2006 , Thailand faced its $18^{\text {th }}$ coup and the first coup after its proud "People Constitution" of 1997. The coup brought about a series of constitution drafting and election which Thaksin's affiliated party won and was able to set up a new government just to be overthrown again. After the 2006 coup, Thailand has been repeating its cycle of coup, constitution and election that the nation eventually encountered the latest coup on May 22nd, 2014, which is less than 8 years apart from the previous coup. Repetitive scenarios of coup, constitution and election portray ties between business and politics and their impacts on the quality of democracy. It shows that politics, including electoral politics, are backed by the bureaucracy and military who hold the real power behind the electoral theatre. Both military and political parties use development and economic growth as justification to retain power.

Looking at the examples of South Korea, Taiwan and Japan, developmental state does not require the state to be authoritarian in order to be qualified as a developmental state. On the other hand, there are many cases of authoritarian countries that failed miserably in developing their economies, such as authoritarian Latin American states under bureaucratic authoritarianism. Therefore, though authoritarianism can facilitate effective intervention in economic and development policies, it does not guarantee economic success (Woo-Cumings, 1999. Pp.52)

Additionally, in globalization era, though it is more difficult for a state to intervene economic policies - because the state must endure international political economic rules of embedded neoliberalism that supports free market, privatization of public enterprises and monetary reform - a neo-developmental state could also adapt itself to cope with democracy and democratic institutional structures and agents that attached to the regime. Hence, that does not mean that the state roles in managing its economy have weaken or ended in globalization era, rather the state has adapted itself to cope with globalization (Micklethwait \& Wooldridge, 2014) (Owen, 2014) (Pongpaichit \& Baker, 2004).

Southeast Asian's developmental state model was created during Lee Kuan Yew's premiership from 1959 - 1990. His opponents were sent to jails and Singaporeans were treated like children. Lee created Singaporean state with components of a modern state, then added the Asian values to it. The Asian alternative of Singapore's model is different from the Western state where "the government should be democratic and generous" because, to the Singaporean model, "the government is elitist and stingy" (Micklethwait and Wooldridge, 2014. Pp. 133 - 137). The model was drawn from Lee's assumptions that Western democracy was no longer efficient; both capitalism and society need to be directed; and getting the government right is the key to the regime's survival and success (Micklethwait and Wooldridge, 2014. Pp. 145).

While Singapore provides an Asian alternative with elitist and stingy government model, China is a more brutal version. Chinese state directs both public and private sectors, especially state-owned companies that dominate strategic industries. More importantly, China's state capital has gone global as its companies have been reaching out abroad. For example, there are several Chinese companies pursuing 
oil, timber, diamonds, copper and iron ore in Africa while other Chinese businessmen are building infrastructures to facilitate the upcoming transactions at site. Therefore, to China, state capitalism has become its main foreign activity (Micklethwait and Wooldridge, 2014. Pp. 146 - 153).

Thailand's nationalism has played its part in the new innovative Pracharat development strategies The word "Pracharat" was selected from the lyrics of the national anthem. The development strategies aim to mobilize the grassroots economy as well as the national economic performance as a whole (The Royal Thai Government, 2015). Expected contents of the strategies include sufficiency economy, green farming, holistic development, livelihood rights, people's participation, bottom-up planning, environmental conservation, and local resource management (Bangkok Post Newspaper, 2015). The Pracharat development strategies will also be included in the 20-year national strategic plan which focuses on sufficiency economy, people-centered development with active participation, promotion and encouragement of national reform, and national development under the vision of "stability, prosperity, and sustainability" (The Royal Thai Government, 2015).

\section{Thailand 4.0 with Wellness Business as A New S-Curve}

The mentioned 3 traps obstruct country's economic development, that is why the country has come up with the new economic development strategies which is Thailand 4.0 model that is comprised of 3 engines of growth.

Productive growth engine. This engine is to move Thailand from middle-income country to highincome country. It is driven by innovation, wisdom, technology and creativity. This cluster aims to foster research and development capabilities and support innovation-led business. Therefore, this productive growth engine shows the effort to overcome the middle-income trap

Inclusive growth engine. This engine aims for income distribution and to create equal opportunity and wealth to response to all social and economic challenges. This engine, also, aims to achieve a build of provincial economic cluster networks and grassroot economic at a community level, to support social enterprises, to create business-friendly environment, to empower SMEs' international competitiveness and to create skilled labor to response to changes in the future. Hence, this inclusive growth engine is there for overcoming inequality trap.

Green growth engine. This engine aims for renewable energy consumption. That is, it shifts from cost advantage method in the past to the more sustainable method, lost advantage. The key to lost advantage is to improve production process so that it affects as least as it can to the environment. This benefits the country and the globe at the same time because the environmentally friendly production process is the answer of how we conquer imbalance trap we have faced in reality.

These 3 engines of Thailand 4.0 model will lead Thailand to become a high-income country where the wealth is well distributed and green/environmentally friendly economic is practices which are the main character of the first world country that Thailand will achieve the status with in the $21^{\text {st }}$ century. (Ministry of Industry, 2016)

According to Health Systems Research Institute (HSRI), Thailand has faced changes in various dimensions that affect health systems. It proposes 11 dimensions of changes, namely consuming and living behaviors; urbanization; aging society; reasonable drug use; environmental change; market competition and investment; technological development; preventable diseases; higher spending on healthrelated activities; healthcare human resource management and inequality in health system (Thailand Board of Investment, 2018).

As well, the Thai government has set "Medical and Wellness Tourism" as the country's development strategy to make Thailand a "hub" for medical and wellness tourism activities since 2002. (Thailand Board of Investment, 2018). With medical and wellness tourism as a "new s-curve" innovation is to ensure that Thailand's economy will continuously develops. That is, the country will profit from the new wave of innovation, while the first s-curve, or the heavy-industry based economy in the past, will eventually fade out. (Ministry of Industry, 2016)

The first s-curve is the industry that Thailand has capabilities to produce, and it is a potential industry that had created tremendous economic value, but it lacked technological improvement and generate low growth rate. On the other hand, the new s-curve industry is a new industry that has intense use of technology and innovation. This is the industry that has great potential growth in the future. 
However, as it is a new industry that acquires low number of players, it requires that the relevant actors must support the industry in order to make it strong and highly competitive in the near future (Ministry of Industry, 2016).

One of the strategies is to reform the Thai industry sector into an innovation industry. To elaborate, the strategy is to transform from production-based activities to innovation and technological based activities by empowering the industry's competitiveness to level up production standard and to create new innovations with digital technology as a key tool. This is to build a network of "Innovation Driven Entrepreneurship" (IDE) who uses innovation and technology in their activities and to support the aggregation of industry cluster. This SPRING strategy is to level up standard, productivity, and innovation. Apart from that to craft sustainable development, the country needs to support green growth industry and cultural and creative entrepreneurs to assure that they achieve 5 elements of development: productivity; standardize; innovation; green growth enterprise and cultural and creative enterprise (Ministry of Industry, 2016).

Wellness business is seen as a new s-curve actor. To elaborate that, the Thailand 4.0 model puts the wellness business, as a new s-curve economic actor, development into following 4 phases.

For 1-2-year timeframe: the strategy is to strengthen new s-curve business/start-ups and to craft them into "New Economic Warrior"; to promote smart SMEs and to develop SMEs Rescue Center and Cultural Industrial Village

For 2-5-year timeframe: the strategy is to accelerate start-ups; to increase the number of smart SMEs; to connect SMEs with Les and to support industry networking

For 2-10-year timeframe: the strategy is to support the Thai entrepreneurs to be known internationally and to connect the Thai entrepreneurs to the high-valued chains in the international market.

For 10-20-year timeframe: the strategy is to push the Thai entrepreneurs to transform themselves to be global leading enterprises (Ministry of Industry, 2016).

The medical and wellness business surely benefits from these public policies. Nevertheless, with all the strategies laid out, they have not incorporated pandemic into the 20-year strategic plan. With COVID19 breaking out in the country, Thailand has now faced huge challenges that it needs to overthrow. The government as well as relevant actors must redesign the strategies to cope with reality. Therefore, this research suggests that the study of the medical and wellness business support from the government and relevant actors, both during and after the COVID-19 pandemic phase, should be further scrutinized to make the story of Thailand 4.0, value-based economy, model entirely complete.

\section{References}

Bangkok Post Newspaper, 2015. Decentralise, or Pracharath Bound to Fail. [Online] Available at:

http:/ / www.bangkokpost.com/opinion/opinion/703540/decentralise-or-pracharath-bound-to-fail

[Accessed 10 March 2021].

Micklethwait, J. \& Wooldridge, A., 2014. The Fourth Revolution: The Global Race to Reinvent the State. London: Allen Lane.

Ministry of Industry, 2016. Thailand Indsutry Development Strategy 4.0. [Online] Available at:

http://www.oie.go.th/assets/portals/1/fileups/2/files/Industrial\%20Master\%20Plan/thailandindustrialdevelopme ntstrategy4.0.pdf

[Accessed 10 May 2021].

Owen, N. G., 2014. Routledge Handbook of Southeast Asian History. New York: Routledge.

Pongpaichit, P. \& Baker, C., 2004. Thaksin: The Business of Politics in Thailand. Chiang Mai: Silkworm Books.

Thailand Board of Investment, 2018. Thailand Investment Review. [Online]

Available at: http://www.boi.go.th/upload/content/TIR_Newsletter_AW_FINAL_24052018_5b0fc23b953f7.pdf [Accessed 20 May 2021].

The Royal Thai Government, 2014. The NCPO Chief Revealed NCPO Vision on 9 Strategies. Twelve National Core Values Are Set for Thai People to Instill and Create Awareness on True Democracy. [Online] Available at: Royal Thai Government:

http://www.thaigov.go.th/en/news-2/item/84749-id84749.html [Accessed 19 January 2021].

Woo-Cumings, A., 1999. The Developmental State. Ithaca: Cornell University Press. 